\title{
ERIC in Cyberspace: Expanding Access and Services ${ }^{1}$
}

\author{
by Robert M.Stonehill and Lynn Smarte
}

\begin{abstract}
:
In recent years, the Educational Resources Information Center (ERIC) system has undergone tremendous changes in the kinds of products and services it offers and the methods by which users can access them. AskERIC, a computer network-based question-answering service and virtual library, exemplifies these changes. This article describes AskERIC, other ERIC gopher sites, the National Parent Information Network, ERIC listservactivity on the Internet, and ERIC's offerings on commercial online services. It also lists resources for librarians who do training sessions on ERIC and sketches ERIC's future direction.
\end{abstract}

More than 20 years after providing the world's first online database, the Educational Resources Information Center (ERIC) has again become a recognized leader in using statc-of-the-iurt technology to support teaching and learning. Historically recognized as an online database primarily used by librarians and scholars, ERIC has evolved into a national network of resources and services available "at the desktop" to educators, pol icymakers, and parents. There are two facets to this evolution: enhancing access to ERIC information and enhancing the information itself.

Enhancing Access. In the last decade, ERIC has expanded from a system that produced one online database to a system that produces a wide variety of online and CD-ROM resources. Online access toERIC information, previously provided only by costly commercial services, is now available through ERIC components, libraries, universities, and government agencicsoften for free. But most important, the advent and increasing availability of advanced telecommunications and clectronic storage and retrieval systems - and espccially the explosive growth of the Internet-have dramatically expanded the ways in which users can now have low-cost, on-demand access to ERIC information.

These developments, when coupled with other initiatives such as obtaining toll-free 800-numbers and Internet addresses for each ERIC component, establishing ACCESS ERIC as a contact point for new users, and creating an active ERIC Partners program, have resulted in a dramatic upsurge in the use of ERIC resources and in requests for ERIC services over the past five years. In
1991, approximately 1 percent of users contacted ERIC Clearinghouses and support components via e-mail; by 1993 , that figure had risen to 19 percent. In 1987, we estimated that the total online usage of the ERIC database amounted to 100,000 hours per year. Now, combining online database use (which has expanded beyond the traditional commercial vendors such as Dialog to include services such as America Online and CompuServe) with CD-ROM and Internet use, it is estimated that ERIC resources are being accessed at a rate as much as ten times greater than that of the mid-1980s.

Despite these impressive gains, we have onlybegun torealize the potential of a universally accessible information superhighway. Today, we estimate that perhaps 10 to 15 percent of the 2.5 million teachers in the United States are connected to the Internet at their schools (although the National Education Association reports that approximately two-thirds of its members have computers and modems at home); tomorrow, we expect all schools, tcachers, and students to have full access to information resources located throughout the world. As a first step toward accommodating this dramatically increased demand for information, ERIC is planning to provide direct, state-of-the-art, userfriendly access to the ERIC database and the AskERIC Virtual Library with technical support and the capability to host hundreds of simultaneous users.

Enhancing the Information. For the first 20 years of its existence, ERIC concentrated on building its bibliographic database, which now contains summaries of approximately 850,000 documents and journal articles. While the database is in many ways

'The following text is based on a presentation made by the authors at the Special Libraries Association 85th Annual Conference, Atlanta, June 1994. 
still the cornerstone of ERIC's information network, ERIC hats been steadily diversifying its products and services-usually in response to user requests.

Examples of these current and future improvements include:

The expansion of the ERIC database to include conmercially published books, machine-readable data files, and multimedia products.

- The provision of full-text access to the materials indexed in the ERIC database, beginning with the ERIC Digests Online file. ERIC Digests-short sunumaries of research and developments in education-are already available in full text on the Internet and in the online and CD-ROM versions of the ERIC database. Beginning in 1995, ERIC will begin providing experimental, full-text, online access to new documents indexed in the database.

- The development, by ACCESS ERIC, of a series of reference and referral databases, including annual editions of a Directory of Educarion-Relared Information Centers, a Calendar of Edicarion-Relared Conferences, and a Direciory of ERIC Information Service Providers. ACCESS ERIC also produces The ERIC Review journal three times a year, which provides an indepth look at trends and issues in education.

The establishment of AskERIC, which includes online question-answering services and the AskERIC Virtual Library; an extensive National Parent Information Network; and an active research and development program applying emerging technologies to the dissemination of education information.

The expansion of ERIC's role inproviding Internet access to third-party information, such as the Educational Testing Service's Test Collection database, CNN Newsroom and Discovery Channel materials, the Public Broadcasting System's Newton's Apple and Academy One lesson plans, and more.

\section{AskERIC on the Internet}

\section{The AskERIC Question-Answering Service}

In 1992, the ERIC Clearinghouse on Information \& Technology, based at Syracuse University, began operating AskERIC, a prototype Internet-based electronic question-answering, help, and referral service. The free question-answering service allows users to "AskERIC" their questions about learning, teaching, information technology, or education administration by sending an e-mail question to askeric @ericir.syr.edu. Drawing on the extensive resources of the ERIC system and an indepth knowledge of all the education resources available on the Internet, AskERIC information specialists respond to queries with a customized e-mail answer. ERIC Clearinghouses provide additional information in their specialty areas when needed.

AskERIC information specialists currently respond to questions from more than 350 people each week. State education networks in New York, Texas, Calif ornia, Massachusetts, Florida, North Dakota, Minnesota, Nebraska, Idaho, and Connecticut are among the networks that feature easy access to AskERIC. Here are some of the information requests posted to AskERIC recently:

Are there any articles on the changed role of the elementary school library in a whole language school?

I am looking for information about states that have implemented nongraded or multigraded classrooms in primary grades.

Please send me any current information available on the topic of flexible scheduling for libraries.

Can you give me information on implementing global education?

Do you have information relating to gender equity in the elementary and secondary classroom?

In 1993, the ERIC Clearinghouse on Elementary and Early Childhood Education, located at the University of Illinois, began collaborating with the ERIC Clearinghouse on Information \& Technology on the Parents AskERIC project. This service provides information to parents, early childhood educators, child care givers, and others interested in the growth, development, and care of children through adolescence. By mid-1994, Parents AskERIC was receiving and responding to more than 50 queries each week.

To send a question to AskERIC or Parents AskERIC, e-mail to askeric@ericir.syr.edu.

\section{The AskERIC Virtual Library}

Another service of AskERIC is the AskERIC Virtual Library, an electronic collection of education resources including more than 600 lesson plans, print and video materials, research summaries, answers to frequently asked questions, and discussion groups for practicing educators and librarians. The Virtual Library also provides access to ERIC Digests and to more than 70 InfoGuides on such topics as chemistry for kids, children's literature, and multicultural education. Each InfoGuide includes a description of the topic covered, a list of approximately 10 citations from an ERIC database search of the topic, descriptions of relevant Internet listservs, and information on other related Internet resources.

Other resources available through the AskERIC Virtual Library include answers to frequently asked questions (FAQs) on topics 
such as scheduling and outcome-based education, Internet guides and directories, bibliographies, information about education conferences, and news from theERIC system. Through AskER IC, users may also access the ERIC database and the Internet sites of various state departments of education.

AskERIC's information base and user base continue to grow. Originally targeted for teachers, library media specialists, and administrators in $\mathrm{K}-12$ settings, AskERIC now serves all individuals interested in education issues. During the first week of the AskERIC Virtual Library's existence (in February 1993), there were 300 user connections to the AskERIC gopher. At present, an average of 11,000 people access the Library each week. The total number of AskERIC gopher transactions for 1994, including searches within the menus of the Library, will exceed one million.

In recentmonth s, the AskERIC Mositic/World-Wide Web frontend and server was introduced. The WWW site enables users to access the Virtual Library in multimedia and hypercard. Plins for this server include creating fully formatted and linked InfoGuides that will allow users to link directly to other resources on the Internet.

AskERIC services have received national recognition and praise from individual users. In 1994, AskERIC wats a finalist for the prestigious Computerworld Smithsonian Award in the catcgory of education and academia. Users often return e-mail messages expressing their appreciation for the information provided, the quick response, and the personalized service provided by AskERIC's information specialists.

There are several ways to access the AskERIC Virtual Library. If you have Gopher or FTP capabilities, connect to ericir.syr.edu. If you have Mosaic, Lynx, or another WWW client, open the URL and connect to: http://eryx.syr.edu, or tel net toericir.syr.edu and type "gopher" at the login prompt.

\section{Other ERIC Gopher Sites}

In late 1993, theERICClearinghouse on Assessment and Evaluation, hosted by The Catholic University of America, followed the lead of the ERIC Clearinghouse on Information \& Technology and became the second clearinghouse to establish an Intemet gopher site. By the end of the year, more than 1,500 users were accessing the Clearinghouse's gopher site wcekly. Materials from more than 60 organizations are now posted at this gopher site. One of the more popular services offered is the Test Locator Service. A collaboration of the ERIC Clearinghouse on Assessment and Evaluation, the Educational Testing Service, the Buros Institute of Mental Measurements, and Pro-Ed, the service helps users gather relevant tests from a database of more than 10,000 test descriptions, identifies where reviews of the tests can be found, and provides advice on how best to select and evaluate the tests. This gopher site also features a comprehensive collection of pointers directing users to various Internet locations for searching the ERIC database and ERIC Digests Online. Users are expected to log onto this site more than 60,000 times by the end of 1994 , executing more than 300,000 transactions.

You can reach the Assessment and Evaluation gopher directly via gopher.cua.edu, under Special Resources.

The ERIC Clearinghouse on Science, Mathematics, and Environmental Education operates a gopher site at The Ohio State University. Users log in approximately 500 times each week to view and download Clearinghouse publications, a list of journals covered by the Clearinghouse, and suggestions for other Internet resources of interest to the science, mathematics, and environmental education communities.

You can connect to the Science, Mathematics, and Environmental Education gopher server at gopher.ericse.ohio-state.ed $u$ and to the World-Wide Web scrver at http://gopher.ericse.ohiostate.edu.

The ERIC Clearringhouse on Reading, English, and Communication at Indiana University also has a World-Wide Web site for Digests and other full-text publications from the Clearinghouse. To access this server, connect to http://www.indiana.edu/ reric_recl. A gopher site is also forthcoming in early 1995. (The address for this site should be available from ericcs (il ucs.indiana.edu after (he new year.)

The level of interest in ERIC electronic resources continues to grow. One way to measure use of ERIC-sponsored gopher sites is to monitor the number of "root logins" or visits by individuals to these electronic libraries. Exhibit 1 shows the number of logins to ERIC gophers starting in February 1993 with the establishment of the AskERIC gopher site.

\section{National Parent Information Network}

The National Parent Information Network (NPIN) is an extensive electronic information service for parents, parent educators, and others working in collaboration with families. 


\section{Exhibit 1}

\section{User Logins to ERIC Internet Gopher Sites}

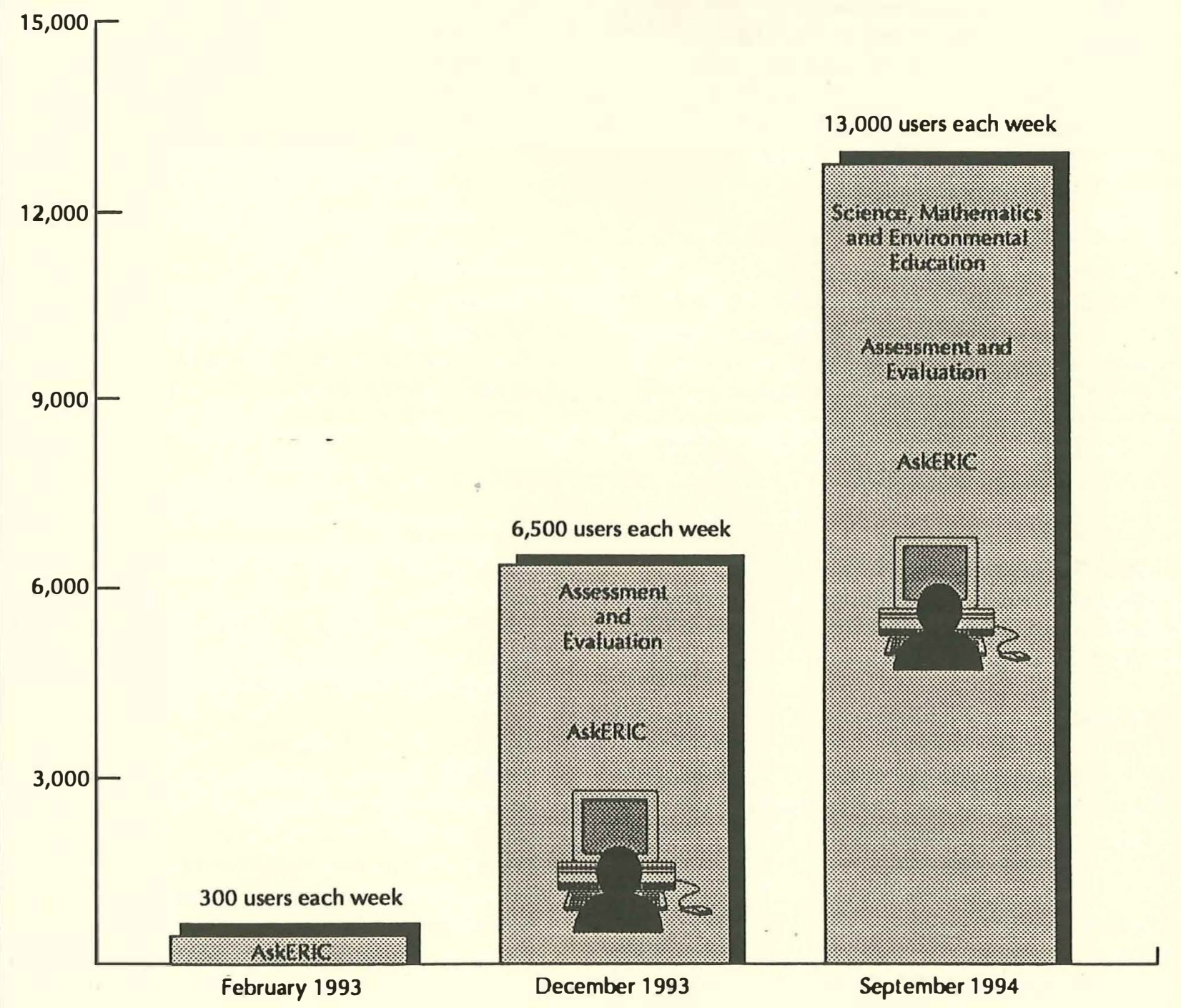


It is being developed by the ERIC Clearinghouse on Elementary and Early Childhood Education and the Columbia University-based ERIC Clearinghouse on Urban Education, in partnership with the National Urban League, several local housing projects, the Illinois Parent Initiative, and Prairienet (the East Central Illinois Freenet).

NPIN offers a continually expanding collection of parentoriented materials from a variety of sources, including the National PTA, the National Urban League, and the Center for Early Adolescence, as well as ERIC. Short articles are available on such topics as childrearing and child development; immunization schedules, nutrition, and other general health concerns; behavior problems; disabilitics; working with children's teachers; and home activities related to math, science, and reading. A question-answering service is being developed that will link parents and parent educators to subject experts in professional associations, ERIC Clearinghouses, and government agencies.

Already available to anyone with an Internet connection, in the near future NPIN will also be accessible through parent centers, public libraries, schools, health clinics, and social service agencies. Thanks to a major equipment grant from Apple Computer, Inc., NPIN will soon be housed on a WorldWide Web server on the Internet that is specifically devoted to child development, care, and education and the parenting of children from birth through adolescence.

To reach the NPIN site, gopher to gopher.prairienet.org and enter the ERIC Clearinghouse in the Education Center or connect to the AskERIC Virtual Library at ericir.syr.ed u and select Other Education Resources. The WWW address is http://www.prairienet.org/htmls/eric/npin/ıpinhome.html.

\section{ERIC and Listservs}

A listserv is an electronic discussion group on the Internet. Several ERIC Clearinghouses have recently started or are currently administering listservs in their topic areas.

- $\quad$ The ERIC Clearinghouse on Educational Management at the University of Oregon launched, with technical assistance from the ERIC Clearinghouse on Information \& Technology, K12ADMIN, a listserv for administrators and individuals with an interest in school administration. Principals, school board members, and teachers are among those joining the listserv and conversing electronically. Usage has increased rapidly, at the rate of about 24 new subscribers each weck. By the end of 1993, about 450 people were registered subscribers to K12ADMIN.

- The Director of the ERIC Clearinghouse on Information \& Technology, Mike Eisenberg, co-coordinates LM_NET, the listserv for school library and media specialists. This discussion group now boasts more than
2,300 members and of fers unique services such as a formal mentoring program; searchable archives, which are located on AskERIC; monitoring of other relevant listservs; and a regularly updated member directory.

- The ERIC Clearinghouse on Elementary and Early Childhood Education maintains three public, unmoderated listservs on the Internet: ECENET on early childhood education, MIDDLE-L on middle level education, and REGGIO-L on the Reggio Emilia education philosophy. MIDDLE-L is a joint effort of the Clearinghouse and the Center for Early Adolescence at the University of North Carolina at Chapel Hill. REGGIO-L, cosponsored by the Merrill Palmer Institute at Wayne State University in Michigan, provides a forum for discussions of the internationally acclaimed municipal early childhood program in Reggio Emilia, Italy. Each of these listservs has between 350 and 400 subscribers.

The AskERIC Virtual Library provides its users with access to a number of education-related listservs, which are archived on the gopher site. This service enables users to browse through the conumunication on several listservs without having to become members. Exhibit 2 shows listservs currently archived on the AskERIC Virtual Library.

\section{ERIC on Commercial Networks}

ACCESS ERIC coordinates with a number of commercial online services to of fer ERIC information to commercial network subscribers. Services such as America Online, CompuServe, GTE Educational Network Services (GTE-ES), and America Tomorrow give ERIC the opportunity to reach millions of current and potential users.

The AskERIC Online section of America Online is the most frequently accessed of ERIC's commercial bulletin boards. America Online users have access to ERIC Digests Online, searchable ERIC Reference and Referral Databases, an ERIC Library of downloadable files and popular ERIC bibliographics, informational brochures, responses to frequently asked questions, and a message board. To date, America Online users have posted more than 1,000 messages and downloaded more than 18,000 ERIC files through AskERIC Online. ERIC information specialists respond to more than 75 queries each weck from America Online users.

ACCESS ERIC staff upload brochures, bibliographies of popular topics prepared by the ERIC Document Reproduction Service, and lead articles from The ERIC Review for CompuServe users. In addition, staff update the ERIC Directory of Education-Related Information Centers, ERIC Calen- 
Exhibit 2

Listservs Archived on the AskERIC Virtual Library

Name

ECENET-L@VMD.CSO.UIUC.EDU

EDNET@nic.umas.edu

Education Policy Analysis Archives

EDPOLYAN@ASUVM.IRE.ASU.EDU

EDTECH@MSU.BITNET

Higher Education Processes Conferences Archives

hs-computing@delos.com

ISED-L@adler.mec.mass.edu

ISLMA@ux1.cso.uiuc.edu

K12ADMIN@suvm.syr.edu

KIDSPHERE-request@vms.cis.pitt.edu

LM_NET@suvm.syr.edu

MIDDLE-L@VMD.CSO.UIUC.EDU

REGGIO-L@VMD.CSO.UIUC.EDU

SATL-CON@SUVM.SYR.EDU

SUPERK12@suvm.syr.edu

vocnet@cmsa.berkeley.edu
Subject

early childhood education

educational potential of the Internet

education policy

educational technology

advanced precollegiate computing education and training independent school educators

Illinois school library media specialists

$\mathrm{K}-12$ educational administration

global network for $\mathrm{K}-12$ children and teachers

(formerly Kidsnet)

school library and media services

middle school education

Reggio Emilia philosophy of early childhood education

U.S. Secretary of Education's Satellite Town Meetings

supercomputing implementation and

utilization in the $\mathrm{K}-12$ environment

vocational education dar of Educarion-Relared Conferences, and Directory of ERIC Information Service Providers quarterly on GTE-ES. Both ACCESS ERIC and the ERIC Clearinghouse on Elcmentary and Early Childhood Education contribute matcrial to the America Tomorrow (ATLIS) network.

FACTOID: From the beginning of 1993 to the middle of 1994, America Online and CompuServe users downloaded 20,724 copies of ERIC materials.

Commercial networks such as America Online and GTE-ES are enhancing their services by providing users with Internet access, which allows them to obtain the whole array of Internet-based ERIC services described earlier in this articlc.

\section{ERIC Training Resources}

In light of the expanded services available through ERIC, education librarians may wish to make use of the following training materials:

\section{ERIC Overhead Transparencies}

ERIC now of fers a set of 33 ERIC overhcad transparency masters that present an introduction to the database, describe the work of the ERIC Clearinghouses, and discuss electronic access to ERIC information. The transparency masters (paper copies) are available free from ACCESS ERIC (see address at the end of this article).

Anyone interested in presenting information about the AskERIC service in workshops or to classes may purchase a set of 15 color transparencies for $\$ 15$ plus $\$ 2$ shipping and handling from the ERIC Clearinghouse on Information \& Technology, Syracuse University, 4- 194 Center for Science and Technology, Syracuse, NY 13244-4100. Phone: 1-800-464-9107 or 315-443-3640. Fax: 315-443-5448. E-mail: eric@ericir.syr.edu.

\section{ERIC Video}

ERIC: In Action offers viewers a broad perspective on ERIC as their premier source for education information. The 15-minute video covers ERIC's basic structure, major benefits,

key index features, and options for locating materials. It is available for $\$ 15$ from the ERIC Clearinghouse on Infornation $\&$ Technology (see address above).

\section{A Pocket Guide to ERIC and All About ERIC}

The Pocket Guide is an 18-page paunphletthat of fers an overview of ERIC products and services and contact information for the ERIC Clearinghouses, support components, online and CD- 
ROM vendors, and reprint services. All About ERIC is a booklet that includes sections for new users and for staff of libraries and resource centers interested in providing access to ERIC. All About ERIC offers basic tips for scarching the database, a reproducible search worksheet, and a haundout for education students called "ERIC Tips for Teachers in Training." Both publications are free from ACCESS ERIC (see address below); bulk copies are available for training.

\section{Curriculum Package}

The ERIC Clearinghouse on Adult, Career, and Vocational Education has prepared an ERIC training curriculum called Your Guide to ERIC (\$30). The package includes four learning modules, transparencies, relevant ERIC publications, and a set of Quick Search Cards, which give step-by-step instructions for searching ERIC on CD-ROM. The modules provide an introduction to ERIC and its products and services; explain what types of documents are included in the database, how they are selected, and how new documents may be submitted; cover types of searches, appropriate descriptors, and search strategies; and describe how to obtain copies of ERIC documents and journal articles as well as other types of information and services from ERIC. Quick Search Cards may also be ordered separately (\$5).

For more information or to order, contact the Center on Education and Training for Employment Publications Off ice, The Ohio State University, 1900 Kenny Road, Columbus, OH 43210 1090. Phone: 1-800-848-4815 or 614-292-4353. Fax: 614292-1260. E-mail: ericacve @magnus.acs.ohio-state.edu.

\section{Future Directions}

In identifying and adopting new strategies for providing a full range of education materials and services, we have begun 10 understand that the next immediate challenge for ERIC is to provide on-demand, free or low-cost, electronic access to a wide varicty of materials in many formats (including video, audio, and hypermedia). We have taken the first steps, but much remains to be done.

Fortunately, ERIC will have new allies in meeting these challenges. In March 1994, the U.S. Congress authorized the establishment of the National Library of Education. ERIC, in conjunction with other key information and technology programs, will be instrumental in the development of the new Library. As it evolves, the Library will become the U.S. Department of Education's one-stop information service where print and online information resources, reference and referral services, and information technology applications will be carefully craf ted to meet the needs and demands of educators, students, and parents. Everyone at ERIC looks forward to participating in this venture.

Robert M. Stonehill, former director of the U.S. Department of Education's ERIC program, is currently Acting Director, State and Local Services Division, U.S. Department of Education, Of tice of Educational Research, Of fice of Research and Dissemination, Washington, D.C., 20208. Phone: 202-219-2088. Fax: 202-219-1817. E-mail: rstonehi@inet.ed.gov.

Lynn Smarte is director of ACCESS ERIC, the outreach component of the ERIC system, sponsored by the U.S. Department of Education. ACCESS ERIC, 1600 Research Boulevard, 3-C, Rockville, Maryland 20850. Phone: 1-800-LET-ERIC (5383742) or 301-251-5467. Fax: 301-251-5767. E-mail: Ismarte (1) inet.ed.gov. 